\title{
Does long-term farmyard manure fertilization affect short-term nitrogen mineralization from farmyard manure?
}

\author{
Leif Nett • Sven Averesch • Silke Ruppel • \\ Jörg Rühlmann • Carmen Feller • Eckhard George • \\ Matthias Fink
}

Received: 8 July 2009 /Revised: 19 October 2009 /Accepted: 20 October 2009 /Published online: 17 November 2009

(C) The Author(s) 2009. This article is published with open access at Springerlink.com

\begin{abstract}
One of the challenges in organic farming systems is to match nitrogen $(\mathrm{N})$ mineralization from organic fertilizers and crop demand for $\mathrm{N}$. The mineralization rate of organic $\mathrm{N}$ is mainly determined by the chemical composition of the organic matter being decomposed and the activity of the soil microflora. It has been shown that long-term organic fertilization can affect soil microbial biomass (MB), the microbial community structure, and the activity of enzymes involved in the decomposition of organic matter, but whether this has an impact on shortterm $\mathrm{N}$ mineralization from recently applied organic substances is not yet clear. Here, we sampled soils from a long-term field experiment, which had either not been fertilized, or fertilized with 30 or $60 \mathrm{t} \mathrm{ha}^{-1}$ year $^{-1}$ of farmyard manure (FYM) since 1989. These soil samples were used in a 10-week pot experiment with or without addition of FYM before starting (recent fertilization). At the start and end of this experiment, soil MB, microbial basal respiration, total plant $\mathrm{N}$, and mineral soil $\mathrm{N}$ content were measured, and a simplified $\mathrm{N}$ balance was calculated. Although the different treatments used in the long-term experiment induced significant differences in soil $\mathrm{MB}$, as well as total soil $\mathrm{C}$ and $\mathrm{N}$ contents, the total $\mathrm{N}$ mineralization from FYM was not significantly affected by soil fertilization history. The amount of $\mathrm{N}$ released from FYM and not immobilized by soil microflora was about twice as high in the soil that had been fertilized with $60 \mathrm{t} \mathrm{ha}^{-1}$ year $^{-1}$ of FYM as compared with the non-fertilized soil $(p<0.05)$.
\end{abstract}

L. Nett $(\bowtie) \cdot$ S. Averesch · S. Ruppel • J. Rühlmann • C. Feller •

E. George $\cdot$ M. Fink

Institute of Vegetable and Ornamental

Crops Großbeeren and Erfurt,

Großbeeren, Germany

e-mail: nett@igzev.de
Keywords Decomposition · Microbial biomass · Organic fertilization $\cdot$ Soil adaptation

\section{Introduction}

Organic farming systems mainly rely on organic fertilizers such as compost, slurry, and animal and green manure to maintain nitrogen $(\mathrm{N})$ nutrition of the crops. Unlike in most mineral fertilizers, the $\mathrm{N}$ contained in organic fertilizers only gradually becomes available after application, through a decomposition process. It is one of the key challenges of organic farming to match $\mathrm{N}$ release from organic fertilizers and crop demand for $\mathrm{N}$. However, predicting $\mathrm{N}$ release from organic fertilizers is complicated because it is influenced by the physico-chemical properties of the added organic material, abiotic factors like $\mathrm{pH}$, temperature, water and clay content of the soil, and the characteristics of the soil microflora involved in the decomposition process. The characteristics of the soil microflora most relevant for the decomposition process include the soil microbial biomass (MB), the microbial community structure, and the actual microbial activity.

Many incubation studies have demonstrated the relationship between carbon (C) and $\mathrm{N}$ mineralization from organic fertilizers and their initial chemical composition. Most authors conclude that the water-soluble $\mathrm{C}$ and $\mathrm{N}$ contents are good predictors of $\mathrm{C}$ and $\mathrm{N}$ mineralization during the first weeks of incubation (e.g., Hadas et al. 2004; Jensen et al. 2005). Contents of more recalcitrant components such as cellulose and lignin have been identified as determining $\mathrm{C}$ mineralization during later stages (e.g., Thuries et al. 2002; Trinsoutrot et al. 2000b), while long-term (months) N mineralization was often found to be well predicted by total $\mathrm{N}$ contents and $\mathrm{C} / \mathrm{N}$ ratios (e.g., Trinsoutrot et al. 2000a) or 
the amount of $\mathrm{N}$ extractable by a neutral detergent (e.g., Jensen et al. 2005).

The soil microflora decomposes organic matter to obtain nutrients or to use parts of it in redox-reactions delivering chemically bound energy to the microorganisms. Soil MB, the community structure, activity, and physiological properties of the soil microflora, such as nutrient use efficiency or cell nutrient concentration, change in response to the availability of organic matter, which in turn has an effect on the decomposition process. Numerous studies have shown that long-term organic fertilization, as compared with long-term mineral fertilization, can increase contents (per mass of soil) of soil organic matter (SOM) and soil MB (e.g., Gunapala and Scow 1998; Houot and Chaussod 1995; Kandeler et al. 1999; Salinas-Garcia et al. 1997), enhance the activities of enzymes involved in the decomposition process (e.g., CarpenterBoggs et al. 2000; Dick et al. 1988), and change the microbial community structure (e.g., Dambreville et al. 2006; Ruppel et al. 2007; Stark et al. 2008). Also, incubation experiments indicate that the easily degradable proportion of $\mathrm{SOM}$, and thus the content of potentially mineralizable $\mathrm{N}$ is increased by long-term organic fertilization (Hadas et al. 1996; Whalen et al. 2001).

Hence, long-term organic fertilization can alter SOM contents, soil MB, soil enzyme activities, and the microbial community structure. It is not clear however, whether this results in long-term fertilization leading to modified decomposition rates of newly added organic matter. This open question is both of academic interest and of practical relevance in fertilizer recommendation systems. Most simulation models predicting $\mathrm{N}$ mineralization from recently added organic matter assume that the decomposition process can be described by first-order kinetics, with a rate constant depending only on the chemical properties of the material and abiotic factors, such as soil temperature and soil moisture (e.g., Abrahamsen and Hansen 2000; Molina et al. 1983). The effects of fertilization history on properties of the soil microflora are not considered. The rationale behind this is that the MB, microbial community structure and microbial activity of soil adjust quickly to newly added organic matter, so that initial properties of the soil microflora can be ignored in the prediction of short-term $\mathrm{N}$ mineralization from organic fertilizer. Most published studies on this issue support this theory (e.g., Fauci and Dick, 1994; Hadas et al. 1996; Langmeier et al. 2002; Stark et al. 2008), although others have found an effect of long-term fertilization history on $\mathrm{C}$ mineralization (Fliessbach et al. 2000) or $\mathrm{N}$ mineralization (Mallory and Griffin 2007) from newly added organic matter.

Many previous studies compared treatments that comprised a combination of different management activities, such as plant protection, tillage operations, cultivated crops, and fertilizer use (e.g., Breland and Eltun 1999; Burger and
Jackson 2003; Gunapala and Scow 1998; Oehl et al. 2004; Sanchez et al. 2001; Stark et al. 2008). However, very few studies compared treatments that differed only in fertilizer inputs. The aim of the present study was to test the hypothesis that long-term organic fertilization has a stimulating effect on short-term $\mathrm{N}$ mineralization from recently added organic fertilizer. We compared treatments that only differed in fertilization history and calculated net $\mathrm{N}$ mineralization from recently added fertilizer on the basis of measured net changes in different $\mathrm{N}$ pools.

\section{Materials and methods}

\section{Soil material}

The soil was taken from a long-term field experiment, which was established on the experimental site in Großbeeren $\left(52^{\circ} 20^{\prime} \mathrm{N}, 13^{\circ} 19^{\prime} \mathrm{E}\right)$ in 1989 . The soil was a loamy sand (Arenic Luvisol) with $810 \mathrm{mg} \mathrm{g}^{-1}$ sand, $140 \mathrm{mg} \mathrm{g}^{-1}$ silt, and $50 \mathrm{mg} \mathrm{g}^{-1}$ clay. In the plow layer $(0-20 \mathrm{~cm})$, the content of organic $\mathrm{C}$ was $6-12 \mathrm{mg} \mathrm{g}^{-1}$, the content of total $\mathrm{N} 0.5-$ $1.0 \mathrm{mg} \mathrm{g}^{-1}$, the soil $\mathrm{pH}$ was 6.5 , and the soil bulk density was $1.6 \mathrm{~g} \mathrm{~cm}^{-3}$ (Rühlmann, personal communication). Three treatments of this field experiment were used in the present experiment: (1) no fertilization since 1989, (2) $30 \mathrm{t} \mathrm{ha}^{-1}$ year $^{-1}$ of fresh farmyard manure (FYM) since 1989, and (3) $60 \mathrm{t} \mathrm{ha}^{-1}$ year $^{-1}$ of FYM since 1989 (corresponding to 6 and $12 \mathrm{t} \mathrm{ha}^{-1}$ year $^{-1}$ of dry FYM, respectively). These treatments will be referred to as "fertilization history". Manure, originated from a dairy cow farm, was applied once a year in autumn or spring during the fallow period. An exclusively horticultural crop rotation with one or two vegetable crops per year was maintained. For the last 5 years (2003-2007), the crops were celery, broccoli/endive, mangold, artichoke, and leek. All crop residues were removed from the field after harvest. The soil samples were taken as composite samples $(n=6)$ from the plow layers of each of the four replicate plots in late February 2008. Keeping the samples from the four field replicates separate generated 12 samples (three fertilization histories $\times$ four field replicates), which were stored for 14 days at $8^{\circ} \mathrm{C}$ in the dark before processing. In the long-term field experiment, soil total $\mathrm{C}$ concentrations (soil $\mathrm{Ct}$ ) and soil total $\mathrm{N}$ concentrations (soil $\mathrm{Nt}$ ) were annually determined using a CNS-Analyzer VARIO EL (Elementar Hanau). Since the plow layer of the soil was carbonate-free, soil $\mathrm{Ct}$ values can be considered as concentrations of organic $\mathrm{C}$.

Greenhouse pot experiment

To investigate the mineralization of $\mathrm{N}$ from recently added FYM, a greenhouse pot experiment was performed. For this 
purpose, each of the 12 field-moist soil samples taken from the long-term field experiment was mixed thoroughly and split into two equivalent samples. One sample was fertilized with $7.6 \mathrm{~g}$ of lyophilized and ground $(2 \mathrm{~mm})$ manure per kilogram of dry soil. These treatments will be referred to as "recent fertilization". The recent fertilization rate corresponded to $60 \mathrm{t} \mathrm{ha}^{-1}$ of fresh FYM assuming a soil bulk density of $1.6 \mathrm{~g} \mathrm{~cm}^{-3}$ and a plow layer depth of $20 \mathrm{~cm}$. Per unit of dry matter, the applied FYM contained $362 \mathrm{mg} \mathrm{g}^{-1}$ total $\mathrm{C}$, $30.4 \mathrm{mg} \mathrm{g}^{-1}$ total $\mathrm{N}$, and $1.3 \mathrm{mg} \mathrm{g}^{-1}$ mineral $\mathrm{N}\left(\mathrm{NO}_{3}{ }^{-} \mathrm{N}+\right.$ $\mathrm{NH}_{4}{ }^{+}-\mathrm{N}$ ). The applied FYM originated from the same cow farm as the FYM applied in the field experiment, which on average for the years 1989 to 2007 contained $363 \mathrm{mg} \mathrm{g}^{-1}$ total $\mathrm{C}$ and $24.7 \mathrm{mg} \mathrm{g}^{-1}$ total $\mathrm{N}$. Immediately after mixing, equivalents of $1.1 \mathrm{~kg}$ of dry soil were fitted in $1.3 \mathrm{~L}$ pots in two replicate sets. A density of approximately $1.1 \mathrm{~g} \mathrm{~cm}^{-3}$ was achieved by compacting the soil in the pots to the same height. Each pot was planted with a fodder radish (Raphanus sativus ssp. oleiformes) seedling, which had newly developed two true leaves and on average, based on a sub-sample of 68 seedlings, contained $1.24 \mathrm{mg} \mathrm{N}$. Fodder radish has a high capacity for $\mathrm{N}$ uptake and was thus used to remove mineral $\mathrm{N}$ from the pot so as to prevent $\mathrm{N}$ losses by denitrification or leaching and to transform the $\mathrm{N}$ into a form that can be readily analyzed at the end of the experiment. In the greenhouse, all pots $(3$ fertilization histories $\times 4$ field replicates $\times 2$ recent fertilization treatments $\times 2$ pot replicates $=48$ ) were arranged in a randomized block design, blocked by pot replicate. All pots were frequently weighed and gravimetric water content adjusted to $160 \mathrm{mg} \mathrm{g}^{-1}$ dry soil (approximately $70 \%$ of water holding capacity). No drainage water from the pots was observed. The duration of the experiment was 70 days from planting on March 14 to harvest on May 23 in 2008. During this period, the average temperature in the greenhouse was $18.6^{\circ} \mathrm{C}(\mathrm{min}$, $11.1^{\circ} \mathrm{C}$ and $\max , 30.1^{\circ} \mathrm{C}$ ), and the average daily irradiance of photosynthetic active radiation in the greenhouse was $87 \mathrm{Wm}^{2}$ (min, $16 \mathrm{Wm}^{2}$ and $\max , 193 \mathrm{Wm}^{2}$ ).

\section{Analyses}

To determine soil mineral $\mathrm{N}$ and soil microbial biomass content, duplicate soil samples were taken at the start and end of the greenhouse pot experiment. The samples from the start were taken after mixing and sieving to $2 \mathrm{~mm}$, but before splitting the samples $(n=12)$ for the fertilization treatment described above (recent fertilization). At the end of the greenhouse pot experiment, the complete soil material of each pot $(n=48)$ was homogenized after removing the fodder radish roots.

For contents of soil mineral $\mathrm{N}\left(\mathrm{Nmin}=\mathrm{NO}_{3}{ }^{-}-\mathrm{N}+\right.$ $\mathrm{NH}_{4}{ }^{+}-\mathrm{N}$ ), the soil samples were kept at $-20^{\circ} \mathrm{C}$ for not more than 5 days prior to analysis. Then a dry mass equivalent of $25 \mathrm{~g}$ of moist soil was extracted with $100 \mathrm{ml}$ of $0.0125 \mathrm{M}$ $\mathrm{CaCl}_{2}$ solution and Nmin concentration was determined colorimetrically in the extract using an EPOS analyzer, Eppendorf, Germany (Bassler and Hoffmann 1997).

To determine soil microbial biomass-C content (Cmic), the substrate induced respiration (SIR) activity was measured at $22^{\circ} \mathrm{C}$ with an automatic infrared gas analyser (Heinemeyer et al. 1989) and the regression equation found by Anderson and Domsch (1978) was used to convert maximum initial respiration rate to Cmic. To measure SIR activity, the gravimetric water content was adjusted to $120 \mathrm{mg} \mathrm{g}^{-1}$ dry soil (approximately $50 \%$ of water holding capacity) and the soil was mixed with glucose at a rate of $3 \mathrm{mg}$ of glucose per gram of moist soil. The samples from the start of the greenhouse pot experiment had been air dried at the start of the experiment and were rewetted and incubated for 2 weeks at $25^{\circ} \mathrm{C}$ prior to SIR analysis. The samples from the end of the experiment were stored at $4^{\circ} \mathrm{C}$ immediately after harvest for a few days prior to SIR analysis. In addition to SIR activity, basal respiration was measured in the same way, but without adding glucose, and the metabolic quotient (qCO2) was calculated as the ratio of basal respiration divided by Cmic. The metabolic quotient reflects changes in substrate and energy use efficiency and can thus indicate changes in the microbial community structure (Anderson 1994). Determinations of SIR activity and basal respiration took place within one month after the end of the pot experiment.

Total plant (shoot+root) dry matter $(n=48)$ was measured at the end of the pot experiment (May 23) after carefully removing soil residues from the roots. Total carbon and nitrogen in the overall plant material (shoot and root material pooled) was determined using a CNSAnalyzer VARIO EL (Elementar Hanau).

\section{Balance calculations}

The simplified mass balance for $\mathrm{N}$ was calculated considering five different pools: plant $\mathrm{N}$, soil mineral $\mathrm{N}$, microbial biomass $\mathrm{N}$, soil organic matter $\mathrm{N}$ (not including the MB), and farmyard manure N. Following components were used.

\footnotetext{
- $\mathrm{N}_{\text {PLANT }}=$

Nplant $_{\text {END }}-$

Nplant $_{\text {START }}$

- $\operatorname{Nmin}_{\text {START }}, \mathrm{Nmin}_{\text {END }}$

Plant $\mathrm{N}$ uptake, calculated as the difference between total plant $\mathrm{N}$ content at the end and start of the pot experiment.

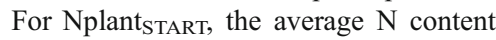
of the fodder radish seedling was used.

Soil mineral $\mathrm{N}$ content at the start and end of the pot experiment. For the treatments that received recent FYM fertilization, Nmin START $_{\text {included the }}$ amount of mineral $\mathrm{N}$ added with FYM (0.0013 $\mathrm{g} \mathrm{N} \mathrm{g}^{-1}$ dry FYM).
} 
- $\Delta \mathrm{Nmic}=\mathrm{Nmic}_{\mathrm{END}}-$

Nmic $_{\text {START }}$

- $\Delta \mathrm{N}_{\mathrm{SOM}}$

$\cdot \Delta \mathrm{N}_{\mathrm{FYM}}$

- available $\Delta \mathrm{N}_{\mathrm{FYM}}$
Net $\mathrm{N}$ immobilization by soil microflora, calculated as the difference of total microbial biomass- $\mathrm{N}$ content between the end and start of the pot experiment, assuming a $\mathrm{Cmic} / \mathrm{Nmic}$ ratio of 10 (e.g., Chapin et al. 2002)

Apparent net $\mathrm{N}$ mineralization (Eq. 1).

$\mathrm{N}$ mineralization from soil organic matter (microbial biomass not included; Eq. 3)

$\mathrm{N}$ mineralization from farmyard manure (Eq. 5)

$\mathrm{N}$ mineralized from farmyard manure that was not immobilized by soil microflora (Eq. 6)
The components $\mathrm{N}_{\text {PLANT }}$, Nmin START $_{\text {Nmin }}$ END, and $\Delta$ Nmic were measured or derived from measurements whereas net $\Delta \mathrm{N}, \Delta \mathrm{N}_{\mathrm{SOM}}, \Delta \mathrm{N}_{\mathrm{FYM}}$, and ${ }^{\text {available }} \Delta \mathrm{N}_{\mathrm{FYM}}$ were calculated as follows. Where necessary, superscript indices $\left(-\mathrm{FYM} /{ }^{+\mathrm{FYM}}\right)$ were used to refer to the treatments with and without recent fertilization with FYM, respectively.

In the first step, net $\Delta \mathrm{N}$ was calculated for every pot according to Eq. 1, assuming that the plants took up only mineral $\mathrm{N}$.

net $\Delta \mathrm{N}=\mathrm{N}_{\mathrm{PLANT}}+\mathrm{Nmin}_{\mathrm{END}}-\mathrm{Nmin}_{\mathrm{START}}$

For the treatments that did not receive a recent fertilization with FYM, it was assumed that net $\Delta \mathrm{N}^{-\mathrm{FYM}}$ consisted of $\Delta \mathrm{N}_{\mathrm{SOM}}{ }^{-\mathrm{FYM}}$ and $\Delta \mathrm{Nmic}^{-\mathrm{FYM}}$ (Eq. 2).

net $\Delta \mathrm{N}^{-\mathrm{FYM}}=\Delta \mathrm{N}_{\mathrm{SOM}}{ }^{-\mathrm{FYM}}-\Delta \mathrm{Nmic}^{-\mathrm{FYM}}$

Hence, $\Delta \mathrm{N}_{\mathrm{SOM}}{ }^{-\mathrm{FYM}}$ could then be calculated according to Eq. 3.

$\Delta \mathrm{N}_{\mathrm{SOM}}{ }^{-\mathrm{FYM}}=\operatorname{net} \Delta \mathrm{N}^{-\mathrm{FYM}}+\Delta \mathrm{Nmic}^{-\mathrm{FYM}}$

For the treatments that received a recent FYM fertilization, net $\Delta \mathrm{N}^{+\mathrm{FYM}}$ included the amount of $\mathrm{N}$ mineralized from $\mathrm{FYM}\left(\Delta \mathrm{N}_{\mathrm{FYM}}\right), \mathrm{N}$ mineralized from $\operatorname{SOM}\left(\Delta \mathrm{N}_{\mathrm{SOM}}{ }^{-\mathrm{FYM}}\right)$ and $\mathrm{N}$ immobilized by soil microflora $\left(\Delta \mathrm{Nmic}^{+\mathrm{FYM}}\right.$; Eq. 4$)$.

net $\Delta \mathrm{N}^{+\mathrm{FYM}}=\Delta \mathrm{N}_{\mathrm{FYM}}+\Delta \mathrm{N}_{\mathrm{SOM}}{ }^{-\mathrm{FYM}}-\Delta \mathrm{Nmic}^{-\mathrm{FYM}}$

Here, $\Delta \mathrm{N}_{\mathrm{SOM}}{ }^{-\mathrm{FYM}}$ was inserted from Eq. 3. Hence, a possible effect of recent FYM fertilization on $\mathrm{N}$ mineralization from SOM (priming effect (PE)) was neglected as it was beyond the scope of this study to determine a possible PE by means of isotope techniques. A study by Blagodatskaya and Kuzyakov (2008) suggests that the PE concerning respired $\mathrm{C}$ can be expected to be zero or negative when the ratio of added substrate $\mathrm{C}$ to microbial $\mathrm{C}$ in the soil is higher than 2. In the present study, this ratio ranged between 27 and 38 .
Equation 4 was then rearranged to give $\Delta \mathrm{N}_{\mathrm{FYM}}$ (Eq. 5). $\Delta \mathrm{N}_{\mathrm{FYM}}=\operatorname{net} \Delta \mathrm{N}^{+\mathrm{FYM}}-\Delta \mathrm{N}_{\mathrm{SOM}}{ }^{-\mathrm{FYM}}+\Delta \mathrm{Nmic}^{+\mathrm{FYM}}$

The amount of $\Delta \mathrm{N}_{\mathrm{FYM}}$ that was not immobilized by soil microflora and thus became available to the plants was calculated according to Eq. 6 .

$$
\text { available } \begin{aligned}
\Delta \mathrm{N}_{\mathrm{FYM}}= & \Delta \mathrm{N}_{\mathrm{FYM}} \\
& -\left(\Delta \mathrm{Nmic}^{+\mathrm{FYM}}+\Delta \mathrm{Nmic}^{-\mathrm{FYM}}\right)
\end{aligned}
$$

Here, the total immobilization by soil microflora was considered, calculated as the difference between $\Delta \mathrm{Nmic}^{+\mathrm{FYM}}$ and $\Delta \mathrm{Nmic}^{-\mathrm{FYM}}$.

\section{Statistics}

All statistical analyses were performed using Statistica 6.1. (StatSoft, Inc, Tulsa, USA). For analysis of variance, the assumption of normal distribution of within-group errors was tested by the Kolmogorov-Smirnov test, while homoscedasticity was checked using the Levene's test. When the preconditions were met, the type VI sums of squares (effective hypothesis) ANOVA was used in combination with the Tukey's HSD multiple comparison procedure. When the assumptions were violated, a Kruskal-Wallis test was used instead. Since the block factor of the replicate pots had no significant effect on any of the investigated variables, it was omitted and statistics were done using mean values for the replicate pots. The level of significance $\mathrm{P}$ was set to 0.05 in all cases. Unless stated otherwise, results are presented as mean \pm 1 standard error of the mean (SEM).

\section{Results}

Effects of recent fertilization

Recent fertilization significantly increased plant $\mathrm{N}$ uptake ( $\mathrm{N}_{\text {PLANT }}$ ) as well as soil mineral $\mathrm{N}$ at the start and end of the pot experiment $\left(\mathrm{Nmin}_{\mathrm{START}}, \mathrm{Nmin}_{\mathrm{END}}\right.$; Tables 1 and 2). Also, the change in microbial $\mathrm{N}$ contents between the start and end of the pot experiment $(\Delta \mathrm{Nmic})$ was significantly affected by recent fertilization (Table 2). For the treatments that received the recent fertilization, net immobilization by the soil microflora occurred whereas without recent fertilization net mineralization was observed (Table 1). Consequently, the microbial $\mathrm{N}$ content at the end of the experiment $\left(\mathrm{Nmic}_{\mathrm{END}}\right)$ was higher for the recently fertilized treatments (Tables 1 and 2). Basal respiration at the end of

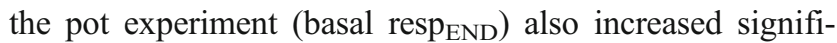


Table 1 Plant $\mathrm{N}$ uptake $\left(\mathrm{N}_{\text {PLANT }}\right)$, soil mineral $\mathrm{N}$ content at the start $\left(\mathrm{Nmin}_{\mathrm{START}}\right)$ and end $\left(\mathrm{Nmin}_{\mathrm{END}}\right)$ of the pot experiment, change in microbial $\mathrm{N}$ during the pot experiment $\left(\Delta \mathrm{Nmic}=\mathrm{Nmic}_{\mathrm{END}}-\right.$
Nmic $_{\text {START }}$ ), microbial $\mathrm{N}$ content at the end of the pot experiment $\left(\mathrm{Nmic}_{\mathrm{END}}\right)$, and basal respiration (basal resp $\mathrm{END}_{\mathrm{EN}}$ ) and metabolic quotient $\left(\mathrm{qCO} 2_{\mathrm{END}}\right)$ at the end of the experiment (means \pm 1 SEM $\left.(n=4)\right)$

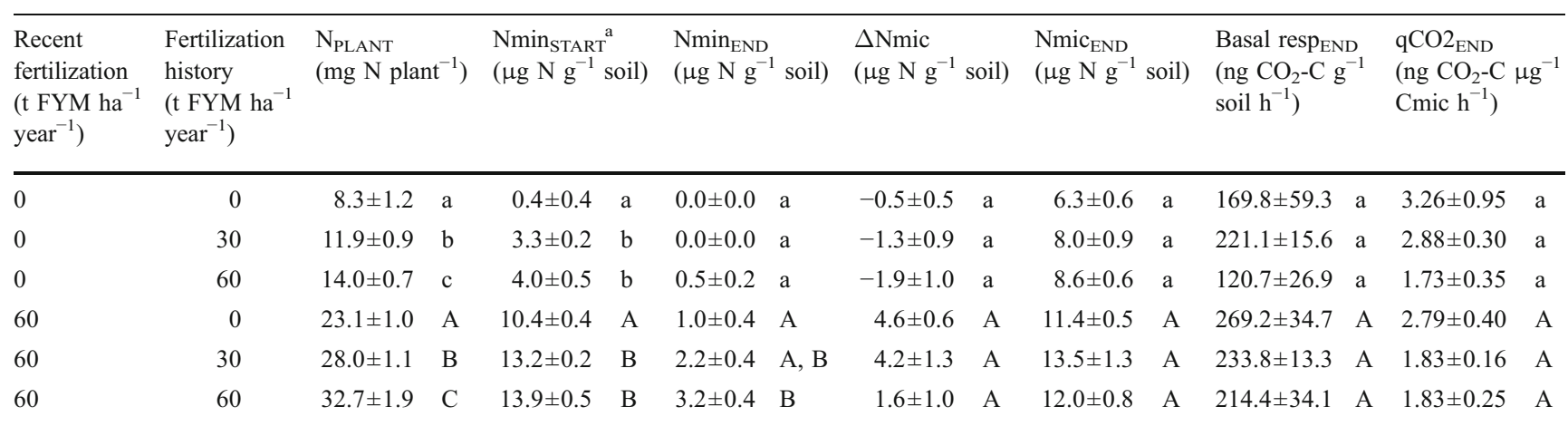

Different letters after values within a column indicate significant differences between history treatments $(p<0.05)$, separately for the treatments with (uppercase letters) and without (lowercase letters) recent fertilization

${ }^{a}$ Includes mineral $\mathrm{N}$ added with FYM for treatments with recent fertilization

cantly due to the recent fertilization whereas the metabolic quotient $\left(\mathrm{qCO} 2_{\mathrm{END}}\right)$ was not significantly affected (Tables 1 and 2).

\section{Effects of fertilization history}

Fertilization history significantly affected soil $\mathrm{Ct}$, soil Nt, and $\mathrm{Nmic}_{\text {START }}$ (Table 3) as well as $\mathrm{Nmin}_{\text {START }}$ and plant $\mathrm{N}$ uptake (N $\mathrm{N}_{\text {PLANT; }}$; Tables 1 and 2). All of these properties increased consistently with increasing fertilization in the field history $\left(0<30<60 \mathrm{t} \mathrm{FYM} \mathrm{ha}^{-1}\right.$ year $^{-1}$; Tables 1 and 3$)$. For the amount of mineral $\mathrm{N}$ measured at the end of the pot experiment $\left(\mathrm{Nmin}_{\mathrm{END}}\right)$, fertilization history only had a significant effect for the treatments that received a recent fertilization, whereas there was no effect for the treatments without a recent fertilization (Table 1), i.e., there was a significant interaction between the two main factors for this variable (Table 2).

The change in microbial $\mathrm{N}$ contents between the start and end of the pot experiment ( $\Delta \mathrm{Nmic})$ as well as microbial biomass $\mathrm{N}\left(\mathrm{Nmic}_{\mathrm{END}}\right)$, basal respiration (basal resp $\mathrm{END}_{\mathrm{EN}}$ ), and metabolic quotient $\left(\mathrm{qCO} 2_{\mathrm{END}}\right)$ at the end of the incubation were not significantly affected by fertilization history (Tables 1 and 2).

The $\mathrm{N}$ mineralization from SOM during the pot experiment as calculated from the treatments without the recent fertilization $\left(\Delta \mathrm{N}_{\mathrm{SOM}}\right.$; Eq. 3$)$ as well as the total net $\mathrm{N}$ mineralization from the recently added FYM $\left(\Delta \mathrm{N}_{\mathrm{FYM}}\right.$; Eq. 5), were not significantly affected by fertilization history (Fig. 1). Also, the immobilization of $\mathrm{N}$ by soil microflora calculated as the difference between $\Delta \mathrm{Nmic}^{+\mathrm{FYM}}$ and $\Delta \mathrm{Nmic}^{-\mathrm{FYM}}$ was not significantly affected by fertilization history (Fig. 1). However, the amount of $\mathrm{N}$ mineralized from recently added FYM that was not immobilized and thus became plant available, was significantly higher in the treatments that had been subject to high fertilization rates in the past ( $60 \mathrm{t}$ of FYM ha ${ }^{-1}$ year $^{-1}$ ) compared with the treatment with no fertilization $(0 \mathrm{t}$ of FYM ha ${ }^{-1}$ year $^{-1}$; Fig. 1).

There was no significant correlation between ${ }^{\text {available }} \Delta \mathrm{N}_{\mathrm{FYM}}$ and Nmic $_{\text {START }}$ but there were significant correlations between ${ }^{\text {available }} \Delta \mathrm{N}_{\mathrm{FYM}}$ and soil $\mathrm{Ct}$, soil $\mathrm{Nt}$, and $\mathrm{Nmin}_{\text {START }}$
Table 2 Two-way ANOVA results ( $p$ values) for the effects of "recent fertilization", "fertilization history", and their interaction on plant $\mathrm{N}$ uptake $\left(\mathrm{N}_{\text {PLANT }}\right)$, soil mineral $\mathrm{N}$ content at the start $\left(\mathrm{Nmin}_{\text {START }}\right)$ and end $\left(\mathrm{Nmin}_{\mathrm{END}}\right)$ of the pot experiment, change in microbial $\mathrm{N}$ during the pot experiment $\left(\Delta \mathrm{Nmic}=\mathrm{Nmic}_{\mathrm{END}}-\mathrm{Nmic}_{\mathrm{START}}\right)$, microbial $\mathrm{N}$ content at the end of the pot experiment $\left(\mathrm{Nmic}_{\mathrm{END}}\right)$, and basal respiration (basal resp $\left.\mathrm{END}_{\mathrm{EN}}\right)$ and metabolic quotient $\left(\mathrm{qCO} 2_{\mathrm{END}}\right)$ at the end of the experiment

\begin{tabular}{|c|c|c|c|c|c|c|c|}
\hline & \multicolumn{7}{|l|}{$p$ value } \\
\hline & $\mathrm{N}_{\text {PLANT }}$ & $\operatorname{Nmin}_{\text {START }}{ }^{\mathrm{a}}$ & $\operatorname{Nmin}_{\text {END }}$ & $\Delta \mathrm{Nmic}$ & $\mathrm{Nmic}_{\mathrm{END}}$ & Basal respend & $\mathrm{qCO} 2_{\mathrm{END}}$ \\
\hline Recent fertilization & 0.0000 & 0.0000 & 0.0000 & 0.0000 & 0.0000 & 0.0245 & 0.2395 \\
\hline Fertilization history & 0.0000 & 0.0000 & 0.0005 & 0.0781 & 0.0885 & 0.1926 & 0.0546 \\
\hline Recent fertilization $\times$ fertilization history & 0.2713 & 1.0000 & 0.0163 & 0.5006 & 0.4379 & 0.3858 & 0.4985 \\
\hline
\end{tabular}

\footnotetext{
${ }^{\mathrm{a}}$ Includes mineral $\mathrm{N}$ added with FYM for treatments with recent fertilization $p$ values $<0.05$ are shown in italics
} 
Table 3 Soil Ct, soil Nt, soil microbial N (Nmic), basal respiration (basal resp), and metablic quotient (qCO2) at the start of the pot experiment, before the application of the recent FYM fertilization treatment (means \pm 1 SEM $(n=4)$ )

\begin{tabular}{|c|c|c|c|c|c|c|c|c|c|c|}
\hline $\begin{array}{l}\text { Fertilization history } \\
\left(\mathrm{t} \mathrm{FYM} \mathrm{ha}^{-1} \text { year }^{-1}\right)\end{array}$ & $\begin{array}{l}\text { Soil Ct }{ }^{\mathrm{a}} \\
\left(\mathrm{mg} \mathrm{C} \mathrm{g}^{-1}\right.\end{array}$ & & $\begin{array}{l}\text { Soil Nt } \\
\left(\mathrm{mg} \mathrm{N} \mathrm{g}^{-1}\right.\end{array}$ & & $\begin{array}{l}\text { Nmic }_{\text {STAR }} \\
(\mu \mathrm{g} \mathrm{N} \mathrm{g}\end{array}$ & & $\begin{array}{l}\text { Basal resp } \text { STAR }^{-} \\
\text {(ng } \mathrm{CO}_{2}-\mathrm{C} \mathrm{g}^{-1}\end{array}$ & $\left(1 \mathrm{~h}^{-1}\right)$ & $\begin{array}{l}\mathrm{qCO}_{\text {START }} \\
\text { (ng CO }_{2}-\mathrm{C} \mu \mathrm{g}^{-1}\end{array}$ & $\mathrm{Cmic}^{-1}$ ) \\
\hline 0 & $6.1 \pm 0.4$ & $\mathrm{a}$ & $0.51 \pm 0.03$ & $\mathrm{a}$ & $6.8 \pm 0.4$ & $\mathrm{a}$ & $140.2 \pm 30.7$ & $\mathrm{a}$ & $1.96 \pm 0.43$ & $\mathrm{a}$ \\
\hline 30 & $7.7 \pm 0.6$ & $a, b$ & $0.65 \pm 0.06$ & $\mathrm{a}$ & $9.2 \pm 0.5$ & $\mathrm{~b}$ & $141.6 \pm 27.0$ & $\mathrm{a}$ & $1.57 \pm 0.28$ & $\mathrm{a}$ \\
\hline 60 & $10.1 \pm 0.2$ & $\mathrm{~b}$ & $0.85 \pm 0.01$ & $\mathrm{~b}$ & $10.5 \pm 0.5$ & $\mathrm{~b}$ & $189.4 \pm 18.2$ & $\mathrm{a}$ & $1.80 \pm 0.12$ & $\mathrm{a}$ \\
\hline
\end{tabular}

Different letters after values within a column indicate significant differences between history treatments $(p<0.05)$

${ }^{\text {a }}$ Significant differences according to Kruskal-Wallis multiple comparisons test $(p<0.05)$

(Table 4), these latter soil properties being strongly intercorrelated (not shown).

\section{Discussion}

Our results showed that contrasting fertilization treatments since 1989 had induced considerable differences in soil Ct, soil Nt, and Nmic START $_{\text {(Table } 3 \text { ). In addition, soil mineral }}$ nitrogen contents at the start of the pot experiment $\left(\mathrm{Nmin}_{\text {START}}\right.$; Table 1) were significantly increased with increasing fertilization rates in the field. This was probably due to different $\mathrm{N}$ mineralization rates caused by different SOM contents in the long-term experiment, from which the soil samples were taken (Rühlmann and Geyer 1993). The calculated $\mathrm{N}$ mineralization from SOM during the incubation, however, was not significantly different between soil histories $\left(\Delta \mathrm{N}_{\mathrm{SOM}}\right.$; Fig. 1$)$, probably due to the short time period covered in the pot experiment. Yet, in comparison to $\mathrm{N}_{\text {PLANT }}$ (Table 1), which varied between 8.3 and $32.7 \mathrm{mg} \mathrm{N}$ pot $^{-1}$ as well as $\Delta \mathrm{N}_{\mathrm{FYM}}$ (Fig. 1), ranging from 10.6 to

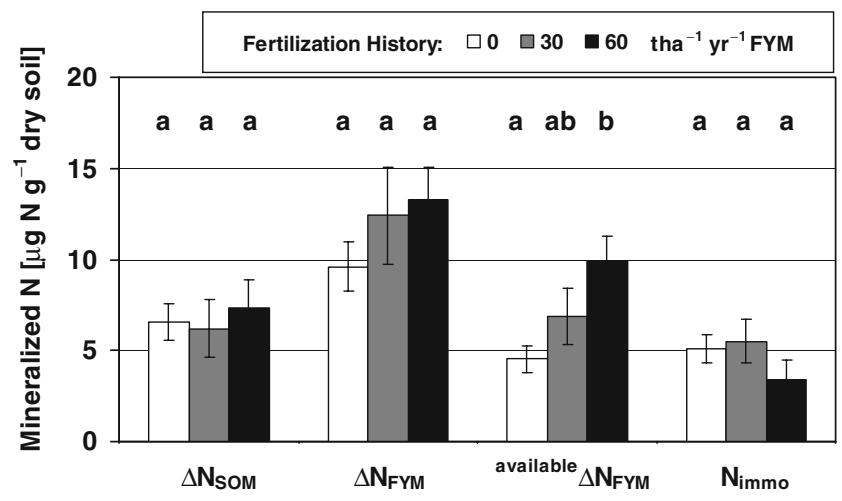

Fig. 1 Calculated amounts of $\mathrm{N}$ mineralized from soil organic matter $\left(\Delta \mathrm{N}_{\mathrm{SOM}}\right.$; Eq. 3$)$ and from farmyard manure $\left(\Delta \mathrm{N}_{\mathrm{FYM}}\right.$; Eq. 5$)$, the amount of $\mathrm{N}$ mineralized from farmyard manure that was not immobilized ( ${ }^{\text {available }} \Delta \mathrm{N}_{\mathrm{FYM}}$; Eq. 6), and the amount of $\mathrm{N}$ that was immobilized by soil microflora $\left(\mathrm{N}_{\mathrm{immo}}\right)$, calculated as the difference between $\Delta \mathrm{Nmic}^{+\mathrm{FYM}}$ and $\Delta \mathrm{Nmic}^{-\mathrm{FYM}}$. Different letters within a variable indicate significant differences between fertilization history treatments $(p<0.05)$. Error bars represent 1 SEM $(n=4)$
$14.6 \mathrm{mg} \mathrm{N}$ pot $^{-1}, \Delta \mathrm{N}_{\mathrm{SOM}}$ was indeed a relevant $\mathrm{N}$ balance component, ranging from 7.2 to $8.1 \mathrm{mg} \mathrm{N} \mathrm{pot}^{-1}$.

Both main factors of the study - fertilization history and recent fertilization - significantly affected several properties of soils, plants, and microorganisms. However, there were no significant interactions between the main factors regarding Nmic $_{\text {END }}$, basal respend, $\mathrm{qCO} 2_{\mathrm{END}}, \mathrm{N}_{\mathrm{PLANT}}$, and $\Delta \mathrm{Nmic}$ (Table 2), so that changes in these properties due to the recent fertilization were not significantly affected by fertilization history. In addition, the total net $\mathrm{N}$ mineralization of the recently added FYM was not significantly affected by fertilization history ( $\Delta \mathrm{N}_{\mathrm{FYM}}$; Fig. 1).

These results are supported by Fauci and Dick (1994), who reported that soils that had received beef manure or pea vine in the past did not respond differently to recent additions of these supplements than soils that had not received the respective supplement before, with respect to microbial $\mathrm{C}$ and $\mathrm{N}$ contents, soil enzyme activity, and respiration. Here, $\mathrm{N}$ mineralization was not measured.

In contrast, Mallory and Griffin (2007) reported a fertilization history effect. They applied farmyard manure to soils that had either been mainly fertilized with organic materials or mainly been fertilized with inorganic materials in the past. They reported that the proportion of $\mathrm{N}$ released as nitrate from recently added manure at the end of a 282-day incubation period was significantly lower in the organically fertilized soil. The authors attributed this effect to more active soil microflora that immobilized more $\mathrm{N}$ from

Table 4 Coefficients of correlations between soil properties and nitrogen mineralization from newly added farmyard manure for the treatments that received a recent FYM fertilization

\begin{tabular}{lcc}
\hline & $\Delta \mathrm{N}_{\mathrm{FYM}}$ & ${ }^{\text {available }} \Delta \mathrm{N}_{\mathrm{FYM}}$ \\
\hline Soil Ct & 0.47 & $0.68^{\mathrm{a}}$ \\
Soil Nt & 0.45 & $0.67^{\mathrm{a}}$ \\
Nmin $_{\text {START }}$ & 0.40 & $0.66^{\mathrm{a}}$ \\
Nmic $_{\text {START }}$ & 0.20 & 0.41 \\
\hline
\end{tabular}

${ }^{\text {a }}$ Significant at $p<0.05$

Mean values for the two pot replications $(n=12)$ were used 
manure than the microflora in the minerally fertilized soil. These authors further argued that one possible reason why their results did not concur with those of Hadas et al. (1996), Langmeier et al. (2002), and Sanchez et al. (2001) was that the pair of contrasting soils they used was far more disparate than in the other studies. After 11 years of contrasting amendment history they found soil Ct $67 \%$ higher and soil $\mathrm{Nt} 79 \%$ higher in the organically fertilized soil than in the minerally fertilized soil. Notably, the soils in the present study did show considerable differences due to the different fertilization histories. Compared with the non-fertilized treatment, the fertilization rate of $60 \mathrm{t} \mathrm{ha}^{-1}$ year $^{-1} \mathrm{FYM}$ resulted in a significant increase in soil $\mathrm{Ct}$, soil $\mathrm{Nt}$, and Nmic, corresponding to $65 \%, 68 \%$, and $54 \%$, respectively (Table 3), but had no significant effect on $\Delta \mathrm{N}_{\mathrm{FYM}}$ (Fig. 1).

$\Delta \mathrm{N}_{\mathrm{FYM}}$ estimates the total net $\mathrm{N}$ mineralization from the recently added FYM while ${ }^{\text {available }} \Delta \mathrm{N}_{\mathrm{FYM}}$ gives the mineralized $\mathrm{N}$ that became plant available, i.e., that was not immobilized by soil microflora. It should be noted that available $\Delta \mathrm{N}_{\mathrm{FYM}}$, which is similar to the $\mathrm{N}$ availability parameter measured by Mallory and Griffin (2007), was significantly affected by field history. However, the availability of $\mathrm{N}$ was higher in the historically fertilized soil, contradictory to the results of Mallory and Griffin (2007). Correspondingly, the observed changes in Nmic during the pot experiment indicated that $\mathrm{N}$ immobilization was lower in the soil that received high organic fertilization in the past as compared with non-fertilized soil and soil that received lower amounts of FYM in the past, although this difference was not significant (Fig. 1). Yet, the immobilized $\mathrm{N}$ corresponded to 53,45 , and $26 \%$ of $\Delta \mathrm{N}_{\mathrm{FYM}}$ for the fertilization history treatments 0,30 , and $60 \mathrm{t} \mathrm{FYM} \mathrm{ha}^{-1}$ year $^{-1}$, respectively. The results suggest that the consistent trend observed in $\mathrm{N}_{\text {PLANT, }}$, which increased with the rate of FYM fertilization in soil history was a combined result of the differences in Nmin $_{\text {START, }} \Delta \mathrm{N}_{\text {SOM }}, \Delta$ Nmic, and, in case of recent fertilization, also of $\Delta \mathrm{N}_{\mathrm{FYM}}$. The significant effect of fertilization history on available $\Delta N_{\mathrm{FYM}}$ was thus in part generated by a non-significant increase in $\Delta \mathrm{N}_{\mathrm{FYM}}$ and in part by a non-significant decrease in $\mathrm{N}$ immobilization with increasing rate of FYM fertilization in soil history.

It should be noted that differences in plant growth and associated root exudation might have had an influence on microbial activity and thus FYM decomposition. However, with the methods used, no conclusions can be drawn concerning this potential feeback effect.

In contrast to our results, Fliessbach et al. (2000) reported that after recent addition of straw a higher proportion of straw $\mathrm{C}$ was both mineralized and assimilated by the soil microflora during 177 days of incubation in soils that had been managed "bio-dynamically" compared with soils that had been managed "conventionally". The authors attributed this to a higher soil MB content as well as more efficient substrate use by the microorganisms in the "bio-dynamic" treatment. However, $\mathrm{N}$ mineralization was not measured in this study.

Hadas et al. (1996) and Langmeier et al. (2002) found no increase in net $\mathrm{N}$ mineralization from recently added organic material in soils that were organically fertilized in the past as compared with non-fertilized or minerally fertilized soils despite higher soil MB contents in the organically fertilized soils. This contradicts the effect of fertilization history on ${ }^{\text {available }} \Delta \mathrm{N}_{\mathrm{FYM}}$ found in our experiment but it is supported by Stark et al. (2008), who reported that the investigated soils-although having distinct microbial community structures due to different fertilization histories - reacted comparably to recent addition of organic material in terms of soil MB contents, enzyme activities, and net $\mathrm{N}$ mineralization.

We did not investigate the microbial community structure but even after 19 years of contrasting treatments, the metabolic quotient measured both at the start and the end of the experiment (Tables 1 and 3), was not significantly affected by field history. This suggests that no relevant shift in the energetic efficiency occurred due to long-term organic fertilization. Hence, it is unlikely that the community structures differed greatly between the different soil fertilization history treatments (Anderson 1994; Ruppel et al. 2007), either before or after the recent application of FYM.

Perhaps the differences found in available $\Delta \mathrm{N}_{\mathrm{FYM}}$ were caused by other factors than initial differences in properties of the soil microflora. The variables Nmic $_{\text {START }}$ and available $\Delta N_{F Y M}$ were significantly affected by fertilization history and were higher in the $60 \mathrm{t} \mathrm{FYM} \mathrm{ha}^{-1}$ year $^{-1}$ treatment compared with the non-fertilized samples. But this does not necessarily mean that the higher microbial biomass had caused the higher $\mathrm{N}$ availability from the recently added FYM. In fact, ${ }^{\text {available }} \Delta \mathrm{N}_{\mathrm{FYM}}$ was not significantly correlated to Nmic START $_{\text {but }}$ bere were significant correlations to soil

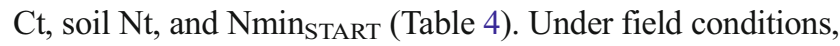
soil $\mathrm{Ct}$ and soil $\mathrm{Nt}$ might affect $\mathrm{N}$ mineralization indirectly, since SOM affects soil temperature und soil moisture, which in turn affect mineralization. These indirect effects, however, were excluded under the controlled conditions of the pot experiment. The results rather suggest that different SOM contents between the fertilization history treatments caused the differences in mineral $\mathrm{N}$ availability at the start of the pot experiment ( Nmin $_{\text {START }}$; Table 1). In turn, these differences had an impact on the decomposing activity of the MB, which was limited by $\mathrm{N}$ availability. It needs to be mentioned that net $\mathrm{N}$ transformation rates as determined in this study can only to a limited extent explain the processes that occurred. Gross nutrient turnover rates determined by means of isotope tracing techniques may contribute to a better understanding of $\mathrm{N}$ transformation processes. 
Finally, it should be considered that during the 10 -week pot experiment on average only $3.2 \%$ of the organic $\mathrm{N}$ applied in FYM (244.4 mg N) was mineralized and became available ( ${ }^{\text {available }} \Delta \mathrm{N}_{\mathrm{FYM}}$ ) and the observed fertilization history effect corresponded to an absolute increase in ${ }^{\text {available }} \Delta \mathrm{N}_{\mathrm{FYM}}$ of $2.4 \%$ of the added organic N. In comparison, Mallory and Griffin (2007) found between $7 \%$ and $27 \%$ of the total N added with manure in the soil nitrate pool after 40 weeks of incubation and Hadas et al. (1996) recovered approximately $26 \%$ of the total added manure $\mathrm{N}$, corresponding to $10 \%$ of organic $\mathrm{N}$ added, after 33 weeks of incubation. A longer experimental duration might have also produced a significant effect of fertilization history on $\Delta \mathrm{N}_{\mathrm{FYM}}$ in our experiment.

In summary, our results confirm that long-term fertilization with organic matter in the field has profound effects on a range of chemical and biological soil properties. These changes can also have an effect on the fate of $\mathrm{N}$ from recently applied organic matter. This effect of fertilization history on soil $\mathrm{N}$ transformations after a recent application of organic matter may be related to different processes, partly investigated in the present experiment. Our data, together with other published evidence, however, suggest that effects of fertilization history on transformation of recently applied organic matter are not always dominant. Therefore it may not be necessary to include such long-term soil memory effects in fertilizer recommendation systems for horticulture and agriculture, at least for short-term crops.

Acknowledgements We thank Ingrid Rathenow for assistance in the greenhouse and Ingo Hausschild for technical support in the laboratory. Financial support from the Ministries of Agriculture of the Federal Republic of Germany, the Brandenburg State, and the Thüringen State is gratefully acknowledged.

Open Access This article is distributed under the terms of the Creative Commons Attribution Noncommercial License which permits any noncommercial use, distribution, and reproduction in any medium, provided the original author(s) and source are credited.

\section{References}

Abrahamsen P, Hansen S (2000) Daisy: an open soil-crop-atmosphere system model. Environ Model Softw 15:313-330

Anderson TH (1994) Physiological analysis of microbial communities in soil: applications and limitations. In: Ritz K, Dighton J, Giller KE (eds) Beyond the biomass - compositional and functional analysis of soil microbial communities. Wiley, Chichester, pp 67-76

Anderson JPE, Domsch KH (1978) Physiological method for quantitative measurement of microbial biomass in soils. Soil Biol Biochem 10:215-221

Bassler R, Hoffmann G (1997) Bestimmung von mineralischem, (Nitrat-) Stickstoff in Bodenprofilen, Nmin-Labormethode. In: Deller B (ed) VDLUFA Methodenbuch Band I, 4. Auflage, 5. Teillieferung 2007, VDLUFA-Verlag, Darmstadt

Blagodatskaya E, Kuzyakov Y (2008) Mechanisms of real and apparent priming effects and their dependence on soil microbial biomass and community structure: critical review. Biol Fertil Soils 45:115-131

Breland TA, Eltun R (1999) Soil microbial biomass and mineralization of carbon and nitrogen in ecological, integrated and conventional forage and arable cropping systems. Biol Fertil Soils 30:193-201

Burger M, Jackson LE (2003) Microbial immobilization of ammonium and nitrate in relation to ammonification and nitrification rates in organic and conventional cropping systems. Soil Biol Biochem 35:29-36

Carpenter-Boggs L, Kennedy AC, Reganold JP (2000) Organic and biodynamic management: effects on soil biology. Soil Sci Soc Am J 64:1651-1659

Chapin FS, Matson PA, Mooney HA (2002) Principles of terrestrial ecosystem ecology III. Springer, New York, pp 1-436

Dambreville C, Hallet S, Nguyen C, Morvan T, Germon JC, Philippot L (2006) Structure and activity of the denitrifying community in a maize-cropped field fertilized with composted pig manure or ammonium nitrate. FEMS Microbiol Ecol 56:119-131

Dick RP, Rasmussen PE, Kerle EA (1988) Influence of long-term residue management on soil enzyme-activities in relation to soil chemicalproperties of a wheat-fallow system. Biol Fertil Soils 6:159-164

Fauci MF, Dick RP (1994) Soil microbial dynamics - short-term and long-term effects of inorganic and organic nitrogen. Soil Sci Soc Am J 58:801-806

Fliessbach A, Mader P, Niggli U (2000) Mineralization and microbial assimilation of C-14-labeled straw in soils of organic and conventional agricultural systems. Soil Biol Biochem 32:11311139

Gunapala N, Scow KM (1998) Dynamics of soil microbial biomass and activity in conventional and organic farming systems. Soil Biol Biochem 30:805-816

Hadas A, Kautsky L, Portnoy R (1996) Mineralization of composted manure and microbial dynamics in soil as affected by long-term nitrogen management. Soil Biol Biochem 28:733-738

Hadas A, Kautsky L, Goek M, Kara EE (2004) Rates of decomposition of plant residues and available nitrogen in soil, related to residue composition through simulation of carbon and nitrogen turnover. Soil Biol Biochem 36:255-266

Heinemeyer O, Insam H, Kaiser EA, Walenzik G (1989) Soil microbial biomass and respiration measurements - an automated technique based on infrared gas-analysis. Plant Soil 116:191-195

Houot S, Chaussod R (1995) Impact of agricultural practices on the size and activity of the microbial biomass in a long-term field experiment. Biol Fertil Soils 19:309-316

Jensen LS, Salo T, Palmason F, Breland TA, Henriksen TM, Stenberg B, Pedersen A, Lundstrom C, Esala M (2005) Influence of biochemical quality on $\mathrm{C}$ and $\mathrm{N}$ mineralisation from a broad variety of plant materials in soil. Plant Soil 273:307-326

Kandeler E, Stemmer M, Klimanek EM (1999) Response of soil microbial biomass, urease and xylanase within particle size fractions to long-term soil management. Soil Biol Biochem 31:261-273

Langmeier M, Frossard E, Kreuzer M, Mader P, Dubois D, Oberson A (2002) Nitrogen fertilizer value of cattle manure applied on soils originating from organic and conventional farming systems. Agronomie 22:789-800

Mallory EB, Griffin TS (2007) Impacts of soil amendment history on nitrogen availability from manure and fertilizer. Soil Sci Soc Am J 71:964-973

Molina JAE, Clapp CE, Shaffer MJ, Chichester FW, Larson WE (1983) Ncsoil, a model of nitrogen and carbon transformations in soildescription, calibration, and behavior. Soil Sci Soc Am J 47:85-91

Oehl F, Frossard E, Fliessbach A, Dubois D, Oberson A (2004) Basal organic phosphorus mineralization in soils under different farming systems. Soil Biol Biochem 36:667-675 
Rühlmann J, Geyer B (1993) Validation of a simulation model for carbon and nitrogen dynamics in soil in a field trial. Acta Horticulturae 339:75-84

Ruppel S, Torsvik V, Daae FL, Ovreas L, Rühlmann J (2007) Nitrogen availability decreases prokaryotic diversity in sandy soils. Biol Fertil Soils 43:449-459

Salinas-Garcia JR, Hons FM, Matocha JE, Zuberer DA (1997) Soil carbon and nitrogen dynamics as affected by long-term tillage and nitrogen fertilization. Biol Fertil Soils 25:182188

Sanchez JE, Willson TC, Kizilkaya K, Parker E, Harwood RR (2001) Enhancing the mineralizable nitrogen pool through substrate diversity in long term cropping systems. Soil Sci Soc Am J 65:1442-1447

Stark CH, Condron LM, O'Callaghan M, Stewart A, Di HJ (2008) Differences in soil enzyme activities, microbial community structure and short-term nitrogen mineralisation resulting from farm management history and organic matter amendments. Soil Biol Biochem 40:1352-1363

Thuries L, Pansu M, Larre-Larrouy MC, Feller C (2002) Biochemical composition and mineralization kinetics of organic inputs in a sandy soil. Soil Biol Biochem 34:239-250

Trinsoutrot I, Recous S, Bentz B, Lineres M, Cheneby D, Nicolardot B (2000a) Biochemical quality of crop residues and carbon and nitrogen mineralization kinetics under nonlimiting nitrogen conditions. Soil Sci Soc Am J 64:918-926

Trinsoutrot I, Recous S, Mary B, Nicolardota B (2000b) C and N fluxes of decomposing C-13 and N-15 Brassica napus L.: effects of residue composition and $\mathrm{N}$ content. Soil Biol Biochem 32:1717-1730

Whalen JK, Chang C, Olson BM (2001) Nitrogen and phosphorus mineralization potentials of soils receiving repeated annual cattle manure applications. Biol Fertil Soils 34:334-341 